\title{
MRI of radial cutaneous nerve abscess in recurrent neural leprosy
}

\author{
Barun Bagga, Chandan Jyoti Das
}

Radiodiagnosis, All India Institute of Medical Sciences, New Delhi, Delhi, India

Correspondence to Dr Chandan Jyoti Das, docchandan17@gmail.com

Accepted 30 November 2018

D) Check for updates

(c) BMJ Publishing Group Limited 2018. No commercial re-use. See rights and permissions. Published by BMJ.

\begin{tabular}{|l|}
\hline To cite: Bagga B, \\
Das CJ. BMJ Case Rep \\
2018;11:e228704. \\
doi:10.1136/bcr-2018- \\
228704 \\
\hline
\end{tabular}

\section{DESCRIPTION}

A 21-year-old man, hailing from Bihar, presented to the clinic with swelling in the right forearm and progressive loss of sensation in the right thumb and index finger and in the radial aspect of the forearm for the last 3 months. He reported that his symptoms started 7 years back when he developed a localised area of loss of sensation over the dorsum of the right hand with hypopigmentation. Skin biopsy was done at the time which was suggestive of leprosy with evidence of activity. The cutaneous leprosy was treated with a WHO multidrug regimen including rifampicin, clofazimine and dapsone for 2 years, and he remained asymptomatic thereafter. At present, on examination, there was a $3 \times 1.5 \mathrm{~cm}$ firm, non-tender swelling over the radial aspect of the right forearm, with $20 \%-40 \%$ loss of sensation over the right forearm (radial aspect near the wrist) and over the right thumb and index finger. The motor examination was within normal limits.

To characterise the swelling and findings detected on clinical examination, magnetic resonance (MR) neurography of the right forearm and wrist was performed. MR neurography clearly showed the presence of thickened, T2 hyperintense, enhancing radial cutaneous and median nerves, with a well-defined, peripherally enhancing T1 hypointense and T2 hyperintense lesion along the radial cutaneous nerve, confirming it to be an

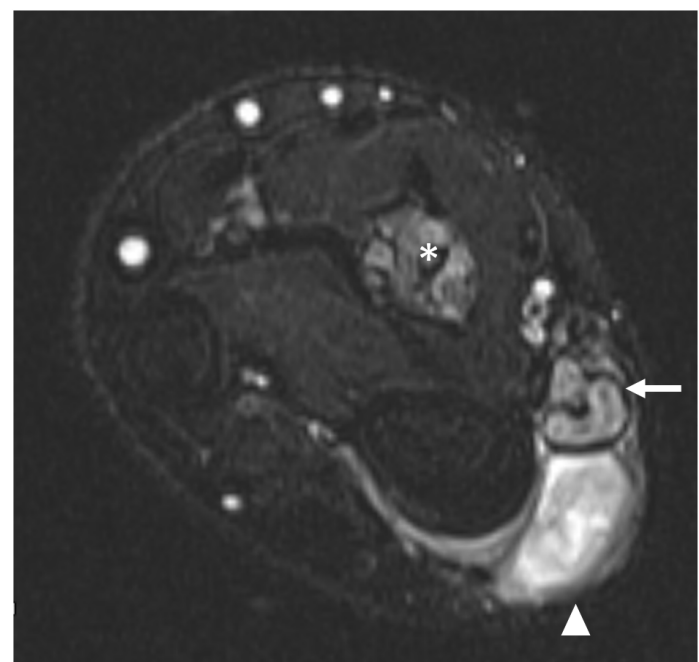

Figure 1 Axial T2 SPAIR (spectral adiabatic inversion recovery) at the mid-forearm showing thickened, $\mathrm{T} 2$ hyperintense superficial radial (marked by arrow) and median (marked by asterisk) nerves with a well-defined T2 hyperintense lesion along the right superficial radial nerve in the subcutaneous plane (marked by arrowhead). abscess (figure 1). Diffusion-weighted whole body imaging with background body signal suppression (DWIBS) showed the presence of an intense central diffusion restriction in the lesion and helped delineate its extent and the relation to the superficial radial nerve (figure 2), which showed diffusion restriction as well. Fine needle aspiration was done from this abscess thereafter, which revealed
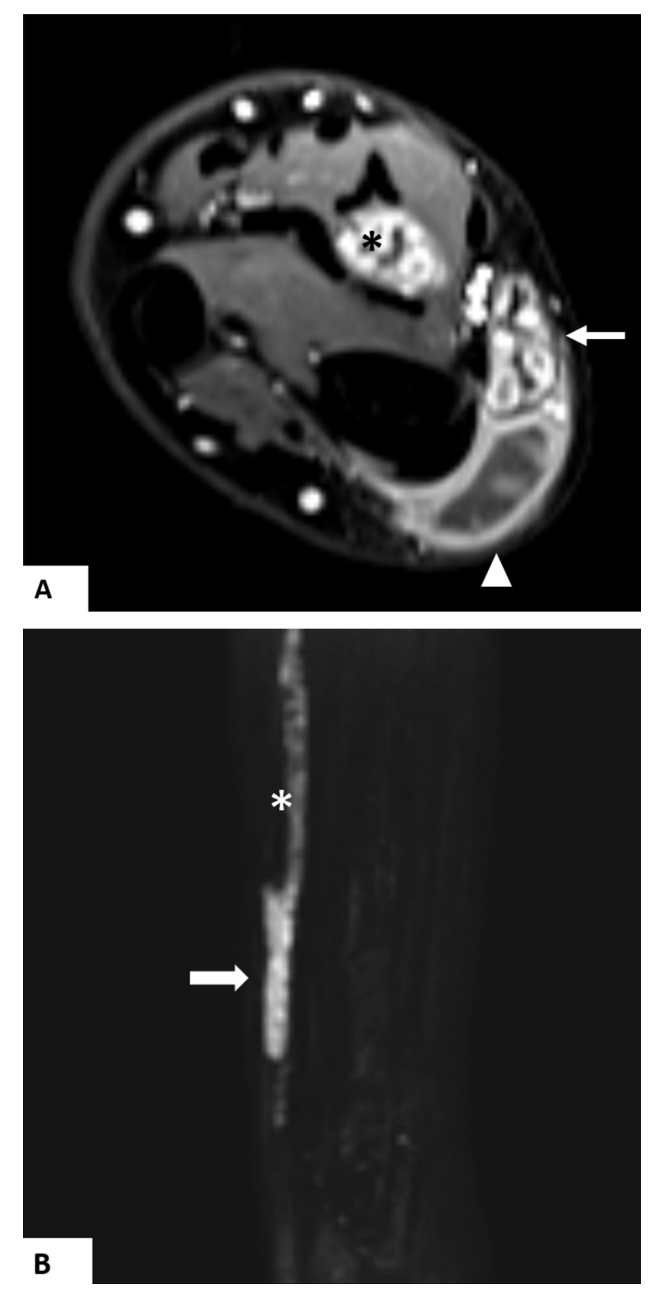

Figure 2 (A) Axial postgadolinium T1-weighted image at the mid-forearm showing enhancing superficial radial (marked by arrow) and median (marked by asterisk) nerves with peripheral continuous enhancement in the lesion along the right superficial radial nerve (marked by arrowhead). (B) Coronal diffusion-weighted whole body imaging with background body signal suppression image showing the extent of the collection in the mid-forearm (marked by arrow) and its relation to the superficial radial nerve (marked by asterisk), which is also showing diffusion restriction. 
granulomatous infiltrates of epithelioid cells, lymphocytes and acid-fast-positive bacilli consistent with Mycobacterium leprae. The patient was started on dapsone, rifampicin and clofazimine with a high dose of steroids. The patient responded well to steroids and surgery was thence deferred.

Nerve abscesses have been reported as a rare complication of neural leprosy, with ulnar nerve being the most commonly involved. ${ }^{12}$ The diagnosis is usually made on clinical ground and sonographic evaluation. However, MR neurography has a niche indication when it is difficult to differentiate other pathologies like nodular neuropathies, soft tissue tumours and nerve

\section{Learning points}

- Nerve abscess should be considered in the differential diagnosis of cutaneous swelling in a setting of neuropathy, especially in leprosy endemic areas.

- Contrast-enhanced magnetic resonance and diffusionweighted imaging help confirm the diagnosis, delineate the extent of involvement and provide guidance for appropriate sampling. sheath tumours, assess the course of the nerves in their entirety, and provide the precise extent of involvement. Peripherally enhancing ulnar nerve abscess on contrast MR in leprosy has been reported with findings on contrast study similar to our case. ${ }^{13}$ However, this is the first study, to our knowledge, to show the role of DWIBS in radial cutaneous nerve abscess in neural leprosy.

Contributors CJD had the idea for the article and is the guarantor of the article. $\mathrm{BB}$ was responsible for the literature search, investigation of the patient and is the writer of this report.

Funding The authors have not declared a specific grant for this research from any funding agency in the public, commercial or not-for-profit sectors.

Competing interests None declared.

Patient consent for publication Obtained.

Provenance and peer review Not commissioned; externally peer reviewed.

\section{REFERENCES}

1 Sen D, Satija L, Chatterii S, et al. Ultrasonography and magnetic resonance imaging of ulnar nerve abscess in leprosy. Med J Armed Forces India 2016;72:78-81.

2 Laxmisha C, Thappa DM, Kumar MS, et al. Pure neural leprosy presenting with multiple nerve abscesses. Indian I Lepr 2004;76:343-50.

3 Hari S, Subramanian S, Sharma R. Magnetic resonance imaging of ulnar nerve abscess in leprosy: a case report. Lepr Rev 2007;78:155-9.

Copyright 2018 BMJ Publishing Group. All rights reserved. For permission to reuse any of this content visit

https://www.bmj.com/company/products-services/rights-and-licensing/permissions/

BMJ Case Report Fellows may re-use this article for personal use and teaching without any further permission.

Become a Fellow of BMJ Case Reports today and you can:

- Submit as many cases as you like

- Enjoy fast sympathetic peer review and rapid publication of accepted articles

- Access all the published articles

- Re-use any of the published material for personal use and teaching without further permission

For information on Institutional Fellowships contact consortiasales@bmjgroup.com

Visit casereports.bmj.com for more articles like this and to become a Fellow 